\title{
A New Mite Species of the Genus Asca (Mesostigmata: Ascidae) from Egypt
}

\author{
M. F. Hassan ${ }^{*}$, H. A. Taha ${ }^{* *}$ and M. A. K. Nasr ${ }^{* *}$ \\ *7oology and Agric. Nematology Dept., laculty of Agric., Cairo Lniv.. Fgypt. \\ ** Plant Protec. Res. Inst.. Agric. Res. Center. Dokki, Giza, Lgypt.
}

\begin{abstract}
Asca aegyptiaca sp.nov., is described from Egypt, the genus is recorded for the first time and collected from leaves and debris of soybean at Menia governorate (Midle Egypt).
\end{abstract}

Key words: Mesostigmata; Ascidae; Asca; new species; soybean.

\section{INTRODUCTION}

Mites of the genus Asca Heyden, are, predatory mites, feed on various arthropods and entomogenous species of nematodes. (Hurlbutt 1963, 1971; Walter 1988; Epsky etal., 1988 and Walter \& Proctor, 1999). Species of this genus are inhabiting leaf litter, soil moss-covered tree trunks in bark beetle gallareis (Stone \& Simpson 1991), termite's and bird's nests (Ryke 1961and Lindquist et al., 2009). Karg (1979) reviewed the genus Asca and mentioned that 75 species were presented in the world, at that time and gave a key for various species. Many species have been described and illustrated by Tseng (1981); Walter et al., (1993); Lee et al., (1997) and Beard et al., (2011).

In Egypt, genus Asca has been recorded for the first time by a new species Asca aegyptiacasp. nov. collected from leaves and debris of soybean at Mallawy, Menia governorate, (Midle-Egypt).The description and illustrations of this new species are given here.

\section{MATERIALS AND METHODS}

Leaf samples were bagged and placed in an ice box until examined. Mites were collected with a fine camel-hair brush, and cleared in Nesbitt's solution before mounting in Hoyer's medium on microscope slides. Measurements in micrometers $(\mu \mathrm{m})$ were made from specimens flattened on microscope slides using a stage-calibrated ocular micrometer and presented in parentheses as ranges (minimum to maximum). Lengths of shields were measured along their midlines, and width between coxae II - III or at their widest point (ventral -anal, dorsal). Setae were measured from the bases of their insertions to their tips and distance between setae as the distance between their insertions. The system of setal notation for the idiosomal and the generic concept of Asca are based on that of Lindquist and Evans (1965). The notation used for leg setation follows that of Evans (1963). Movable cheliceral digits were measured from their basal articulation to their tips. Legs measured from base of coxae to tips of tarsi (without pretarses). The term "pore" and "fissure" used in descriptions are applied to all pore - like structures and includes both sense organs and glands.

\section{RESULTS AND DISCUSSION}

\section{Genus: Asca von Heyden}

Asca von Heyden, 1826: 610. Type species Gamasus aphidisides Fabricius, 1805, by original designation (=Acarus aphidioides L., 1728) Ceratozercon Berlese, 1910: Type species: Zercon bicornis Berlese, 1887 (not Gamasus (Sejus) bicornis Canestrini \& Fanzango, 1876) by subsequent designation (Berlese 1913) (=Acarus aphidioides L., 1758). Synonomy by Vitzthum (1929) cited by Halliday et al., 1998: 17.

Diagnosis: Dorsal shield divided, with pair of posterior projection (horns) on opisthosomal shied usually bearing setae $Z_{4}$ and $S_{5}$. Female with expanded ventrianal shield incorporating 5-6 pairs of ventral setae (usually $\mathrm{Jv}_{2-5}, \mathrm{Zv}_{2-3}$ ) in addition to circumanal setae. Genu I lacks ventral setae av2 (and so having 12 rather than 13 setae). Third pair of sternal pores $\left(\operatorname{stp}_{3}\right)$ on the sternal shield; fourth pair of sternal setae $\left(\mathrm{st}_{4}\right)$ free on soft cuticle. Movable digit of chelicerae usually bidentate.

\section{Asca aegyptiaca sp. nov.}

Diagnos is: This species is similler to A. garmani Hurlbutt, 1963. but differes mainly in: setae $\mathrm{J}_{4}$ and $Z_{5}$ are slightly barbed, whearse seta $\mathrm{J}_{4}$ coarsly barbed and seta $Z_{5}$ smooth in A. garmani; there is procurved ridge between setae $\mathrm{j}_{5}$, whearse this character is absent in A. aegyptiaca; fixed digit of chelicera having 7 teeth in $A$. aegyptiaca, whearse A. garmani has 5-6 teeth; setae $\mathrm{ad}_{2}$ and $\mathrm{pd}_{2}$ on tarsus IV (Fig. 9) whip-like in $A$. aegyptiaca, whears in A. garmani simple.

Description: Female (Figs. 1-9) light brown, anterior dorsal shield (140-155) $\mu \mathrm{m}$ long, (133-147) $\mu \mathrm{m}$ width; bearing 17 pairs of coarsely barbed setae $\left(j_{1}-j_{6}, z_{2}-z_{6}\right.$ and $\left.s_{1}-s_{6}\right)$ setae $r_{2}-r_{5}$ inserted in soft 


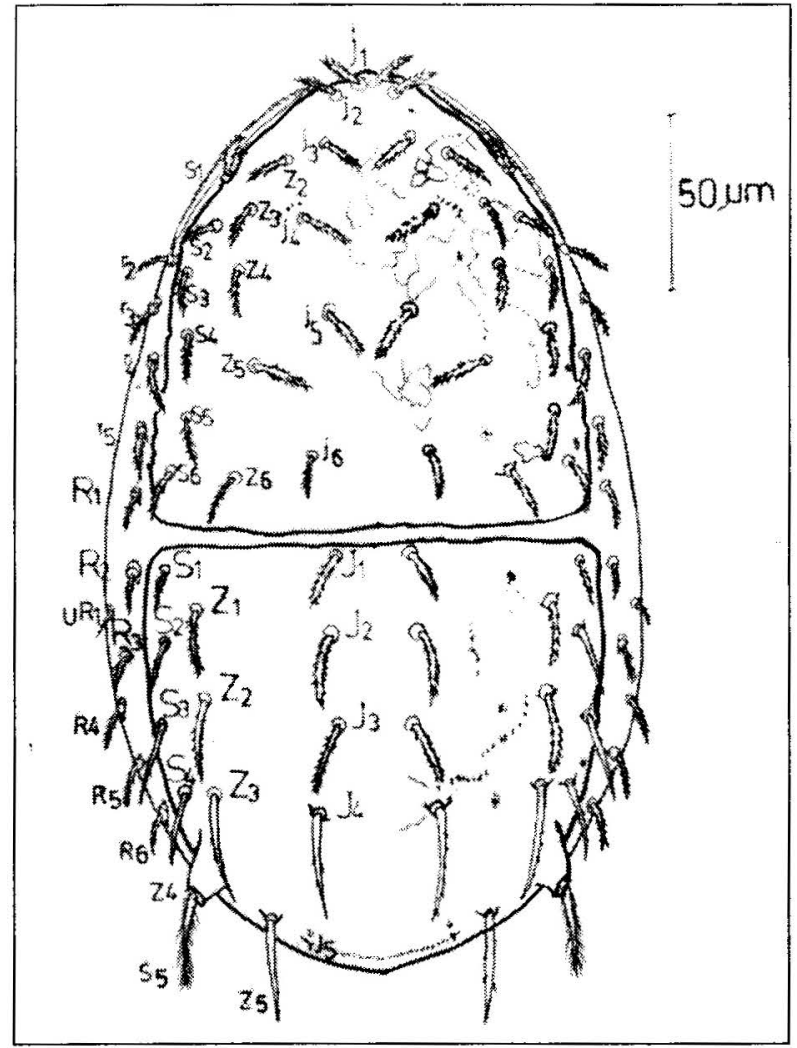

Fig.(1): Asca aegyptiaca sp. nov. dorsal view.

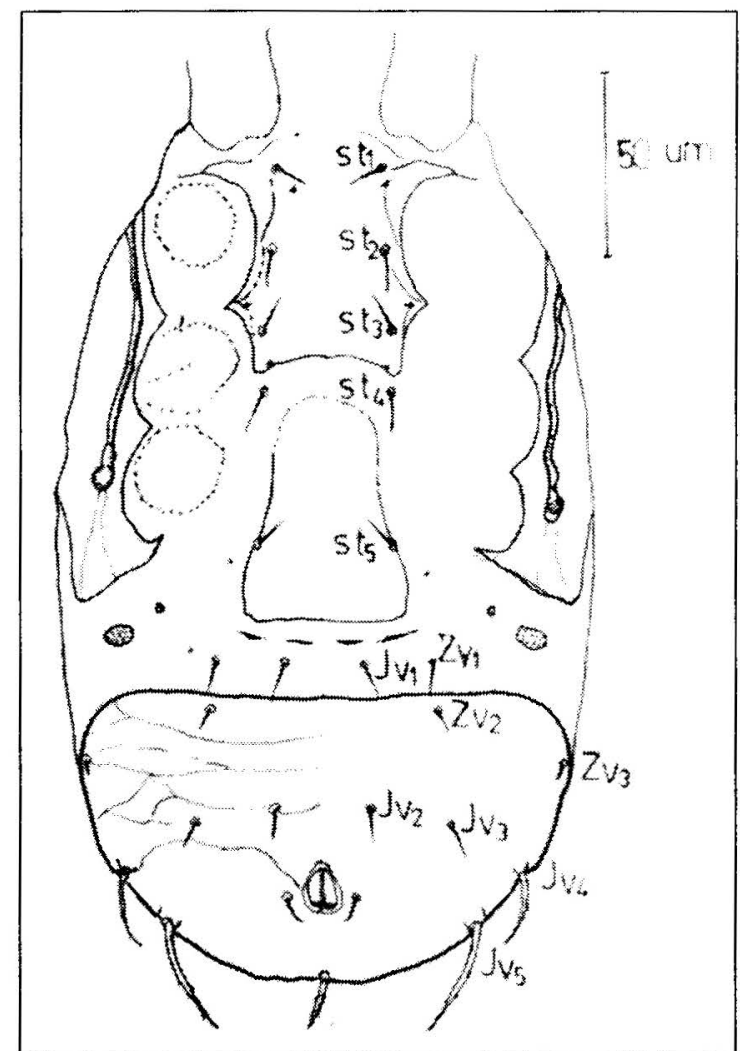

Fig.(2): Asca aegyptiaca sp. nov. ventral view.

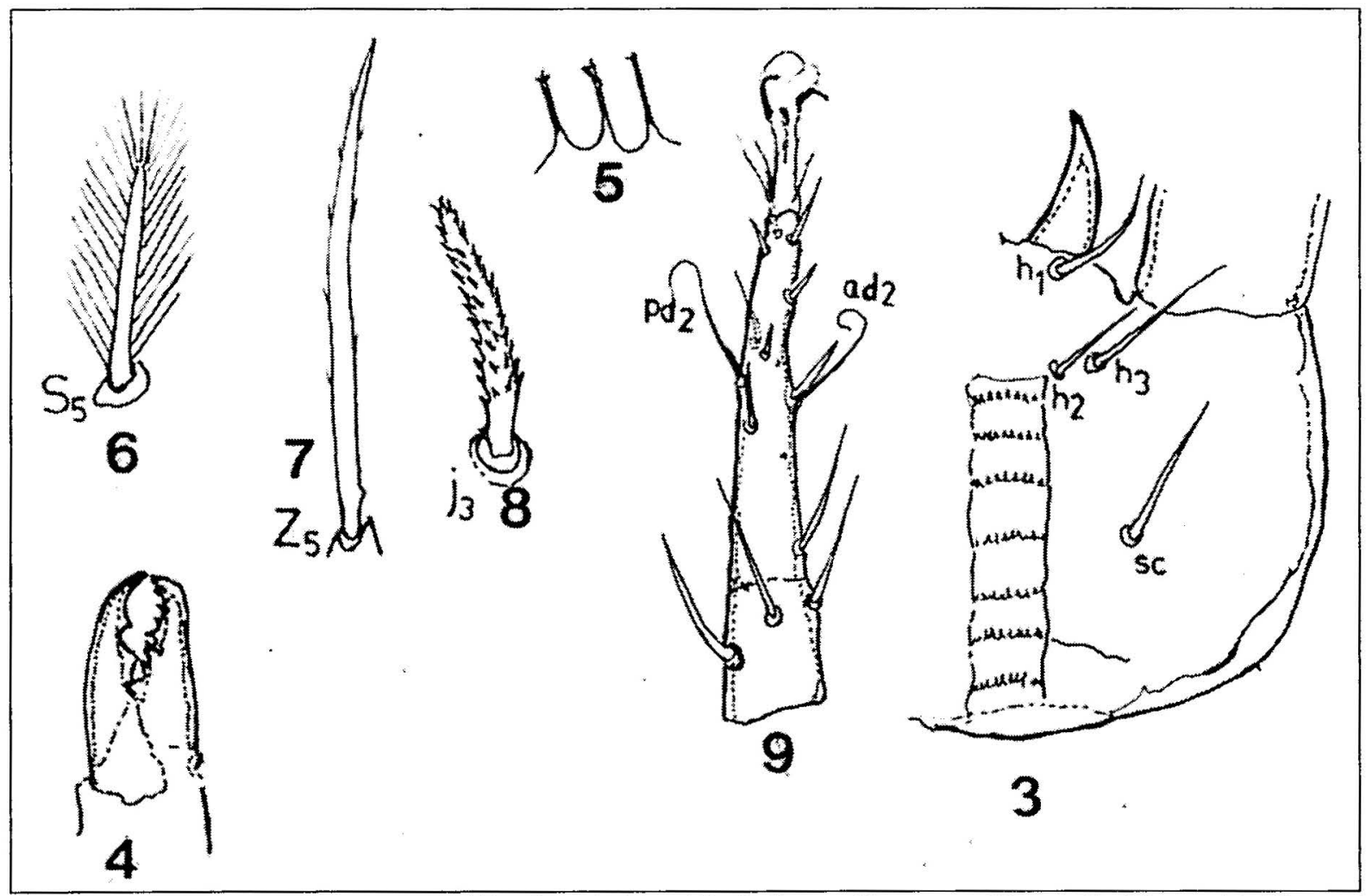

Figs.(3-9): Asca aegyptiaca sp. nov. (3) subcapitulum (4) chelicera (5) tectum (6) seta $\mathrm{S}_{5}$ (7) seta $\mathrm{Z}_{5}(8)$ seta $\mathrm{j}_{3}$ (9) tarsus. 
cuticle laterally; shield generally smooth. except with scattered reticulations, and some scatter rows of minute protuberances on area between setae $j_{4}$ and $z_{3}$ : it appears to have six pairs of pore-like structures. distributed as in Fig.l. Measurements of setae: $\mathrm{j}_{1} \cong \mathrm{j}_{2}$ $\cong \mathrm{r}_{2} \cong=(14-18 \mu \mathrm{m}), \mathrm{j}_{3} \cong \mathrm{j}_{6} \cong \mathrm{s}_{1} \cong \mathrm{z}_{4} \cong \mathrm{s}_{4} \cong \mathrm{s}_{5} \cong \mathrm{r} 5=(16-$ $19 \mu \mathrm{m}) \mathrm{j}_{4}-\mathrm{j}_{5}=\mathrm{z}_{5}=\mathrm{r}_{5}=\mathrm{s}_{6}=(17-20 \mu \mathrm{m})$. Posterior dorsal shield (129-142 $\mu \mathrm{m})$ long $(143-155 \mathrm{Mm})$ width, smooth, except some oblique rows of minute protuberances between $\mathbf{J}$ series and $Z$; bearing 15 pairs differ in length $\left(J_{1}-J_{5}, Z_{1}-Z_{5}\right.$ and $\left.S_{1}-S_{5}\right)$ and barbed setae; postero-lateral horns bearing pinnate conspicuous $\mathrm{S}_{5}(32-35 \mu \mathrm{m})$ long, and minute, vestigial $Z_{4}$; setae $J_{5}$ minute $(2-4 \mu \mathrm{m}) 6$ long. Setae $R_{1}-R_{6}$ and $U R_{1}$ coarsely barbed, and inserted in soft cuticle laterally; length of setae $J_{1}=(18-20 \mu \mathrm{m})$, $\mathrm{J}_{2}=\mathrm{J}_{3}(24-26 \mu \mathrm{m}), \mathrm{J}_{4}(33-37 \mu \mathrm{m}), \mathrm{Z}_{1}(18-23 \mu \mathrm{m}) \mathrm{Z}_{2}$ (26-30 $\mu \mathrm{m}), Z_{3}(35-39 \mu \mathrm{m}) Z_{5}(34-39 \mu \mathrm{m}), \mathrm{S}_{1}(14-16$ $\mu \mathrm{m}) \mathrm{S}_{2}(24-27 \mu \mathrm{m}), \mathrm{S}_{3}(29-31 \mu \mathrm{m}), \mathrm{R}_{2}(18-20 \mu \mathrm{m})$, $R_{2}=R_{3}=R_{4}=R_{5}=R_{6}(18-22 \mu \mathrm{m}) R_{1}(10-13 \mu \mathrm{m})$, setae $J_{4}, Z_{3}, Z_{5}, S_{2} S_{3}$ and $S_{4}$ are slightly barbed; while the remain setae are coarsely barbed. Distances between sockets of setae as: $J_{1}-J_{1}=J_{2}-J_{2}(25-28 \mu \mathrm{m})$, $\mathrm{J}_{2}-\mathrm{J}_{2}(26-30 \mu \mathrm{m}) \mathrm{J}_{4}-\mathrm{J}_{4}=\mathrm{J}_{4}-Z_{3}(35-28 \mu \mathrm{m})$; a row of dentition at the posterior end of the shield is present. Peritreme extends to level seta $\mathrm{j}_{2}$; peritrematal shield fused to dorsal shield from $r_{2}$ to level of $j_{2}$ anterolaterally.

Ventral idios oma (Fig. 2): Jugular is indistinct, bears seta $\mathrm{st}_{1}$, sternal shield, smooth medially, weakly sclerotized, undefined antieriotly and with slightly concave posterior margin, bearing $\mathrm{st}_{2}$ and $\mathrm{st}_{3}$, having 3 pairs of pore-like structure, with oblique longitudinal lines laterally; distances of $\mathrm{st}_{1}-\mathrm{st}_{2}$ (31-35 $\mu \mathrm{m}), \mathrm{st}_{2}-\mathrm{st}_{2}(33-37 \mu \mathrm{m})$ and $\mathrm{st}_{2}-\mathrm{st}_{3}(40-45 \mu \mathrm{m})$ setae $s t_{4}$ on soft cubical free posterolaterally of sternal shield. Metasternal shield absent. Genital shield, smooth, truncate posterior margin, bearing a pair of genital seta (st $\left.)_{5}\right)$. Two pairs of ventral setae $\left(\mathrm{Jv}_{1}, \mathrm{Zv}_{1}\right)$ and a pair of pores in plicate soft cuticle anterior to ventrianal shield, two pairs of circular metapodal platelets, outer one larger. Ventrianal shield, with slightly concaved anterior margin, reticulated by 4 transverse rows and connected with little rows laterally, bearing 6 pairs of ventral setae $\left(\mathrm{Jv}_{2-5}, \mathrm{Zv}_{2}\right.$, $Z v_{3}$ ); setae $J_{v_{4}}$ and $J v_{5}$ curved and finely barbed; postanal seta thick, barbed and longer than para-anals. Distances between sockets of some setae: $\mathrm{st}_{4}-\mathrm{st}_{4}$ $(39-45 \mu \mathrm{m}) \mathrm{st}_{5}-\mathrm{st}_{5}(44-45 \mu \mathrm{m}), \mathrm{JV}_{1}-\mathrm{Jv}_{1}(24-28 \mu \mathrm{m})$, $\mathrm{Zv}_{2}-\mathrm{Zv}_{2}(75-80 \mu \mathrm{m}), \mathrm{Jv}_{3}-\mathrm{Jv}_{3}(29-33 \mu \mathrm{m}), \mathrm{Zv}_{3}-\mathrm{Zv}_{3}$ $(136-144 \mu \mathrm{m})$ and $\mathrm{Jv}_{5}-\mathrm{Jv}_{5}(90-98 \mu \mathrm{m})$. Spermathecal apparatus indistinct.

Gnathosoma (Fig. 3): Movable digit of chelicerae $(22-25 \mu \mathrm{m})$ with two large teeth while fixed digit $(20-22 \mu \mathrm{m})$ with a row of 6-7 teeth, short, sharp setiform pilus dentilis, and subapical off-set bifid tooth. Palp setation of trochanter- tibia (normal for the genus) 2-5-6-12; palp apotele two-tined, subcapitulum (Fig: 3) with 7 rows of $8-10$ of deutosternal denticles: corniculi horn - like. curved internally with sharp tip, setae $h_{1}$ subequal to $h_{3}$ and C.s and longer than $h_{2}$; all simple.

Tectum (Fig. 5): Apex with 3 equal tines, each with denticulated tips. Setation of legs 1-IV: Coxae 2-2-2-1, trochanters 6-5 5-5, femora 12-10-6-6, genua 12-11-8-9, tibiae 13-10-8-10, tarsi II -IV 17-17-17; Genua III seta al2 present, tarsus IV (Fig.9) setae $\mathrm{ab}_{2}$ and $\mathrm{pd}_{2}$. flagellated (50-58 $\left.\mu \mathrm{m}\right)$ long (excluding pretarsus).

\section{Male: unknown.}

Remarks: According to the concept of karg (1979). A. aegyptiaca sp. nov., belongs to Asca aphidioides species group, which charactized by: having a single large seta on each posterior horn (another minute seta is also present), minute seta $J_{5}$, an essentially triramous apex ta the tectum, and small tooth like tubercles on the posterior dorsal shield, Walter et al. (1993). Asca aegyptiaca is close to A. garmani, A. afroaphidioides Hurlbutt, 1971 and A. aethiopica Ryke, 1961. About the differences between $A$. garmani and the new species, is mentioned with diagnoses; while A. afroaphidioides differs mainly by setae $S_{4}, Z_{5}$ and $R$ series being simple, whereas in the new species, setae $S_{4}$ and $Z_{5}$ are slightly barbed and $R$ series are coarsely barbed;A. aethiopica with ornamentated anterior dorsal shield, whereas in $A$. aegyptiaca this shield seems to be smooth except some scattered reticulations and some rows of minute protuberances on area between setae $\mathrm{j}_{4}$ and $\mathrm{z}_{4}$, also seta $J_{4}$ sub equal to $J_{3}$ and both coarsely barbed whereas in $A$. aegyptiaca $\mathrm{J}_{4}$ slightly barbed and longer than $J_{3}$ (coarsely barbed).

\section{Material Examined:}

Holotype: Collected from leaves of soybean (Glycine $\max (\mathrm{L}$.) on 13 October, 2014.

Paratypes: Four females, with the same data of holotype.

\section{REFERENCES}

Beard, J.; Ochoa, R. and Vega, F. E. 2011. A new Asca (Acari: Mesostigmata: Ascidae) from Costa Rica. Syst. Appl. Acarol., 16(1): 7-20.

Epsky, N. D.; Walter, D. E. and Capinera, J. L. 1988. Potential role of nematophagous microarthropods as biotic mortality factors of entomogenous nematodes (Rhabditida: Steinernematidae, Heterorhabditidae). J. Econ. Entomol., 81: 821-825.

Evans, G. O. 1963. Observations on the chetotaxy of the legs in the free-living Gmasina (Acari: 
Mesostigmata). Bull. Brit. Mus. (Nat. Hist.) Zool.,10: 277-303

Halliday. R. B.: Walter, D. E. and Lindquist, E. E. 1998. Revision of the Australian Ascidae (Acarina: Mesostigmata). Invertebrate Taxonomy, 12: 154 .

Hurlbutt, H. W. 1963. The genus Asca Heyden (Acarina: Mesostigmata) in North America, Hawaii and Europe. Acarologia, 5: 480-518.

Hurlbutt, H. W. 1971. Ascinae and Podocinae (Acarina: Mesostigmata) from Tanzania. Acarologia, 13 (2): 280-300.

Karg, W. 1979. Die Gattung Hypoaspis Canestrini, 1884 (Acarina, Parasitiformes). Zoologische Jahrbücher Abteilung für Systematik, Ökologie und Geographie der Tiere, 106: 65-104.

Lee, W. K.; Lee, S. Y. and Ryu, M. O.1997. Taxonomic Studies on the genus Asca (Ascidae: Mesostigmata) in Korea II. Description of two new species. The Korean Journal of Systematic Zoology, 13(1): 33- 44.

Lindquist, E. E. and Evans, G. O. 1965. Taxonomic concepts in the Ascidae, with a modified setal nomenclature for the idiosoma of the Gamasina (Acarina: Mesostigmata). Memoirs of the Entomological Society of Canada, 47:1-59.

Lindquist, E. E.; Krantz, G. W. and Walter, D. E. 2009. Order Mesostigmata. In: Krantz, G. W. and Walter, D. E. (Eds.), A Manual of Acarology. Texas Tech University Press, USA, 124-232.

Ma, L. M. 2005. New species of the genera
Gamasellus and Asca. with supplemental description of known species of the genus Asca (Acari: Mesostigmata, Rhodacaridae ). Acta Zootaxomica Sinica, 30 (3): 538-544.

Ryke, P. A. J. 1961. A review of the genus Asca von Heyden with descriptions of new species (Acarina: Mesostigmata: Rhodacaridae). Zoologischer Anzeiger, 167: 127135.

Stone, C. and Simpson, J. A. 1991. Effect of six chemicals on the insects, mites, nematodes and fungi associated with Ips grandicollis (Eichhoff) (Coleoptera: Scolytidae) in Northeastern New South Wales. Journal of the Australian Entomological Society, 30: 21-28.

Tseng, Y.H. 1981. The mite family Ascidae from(II) - Genus Asca Heyden(Acarina: Mesostigmabnta). J. Entomol., 2: 7- 25.

Waiter, D. E.; Halliday, R. B. and Lindquist, E. E. 1993. A review of the genus Asca (Acarina: Ascidae) in Australia, with the description of three new leaf inhabiting species. Invertebrate Taxonomy,7: 1327-1347.

Watter, D. E. 1988. Nematophagy by soil arthropods from the shortgrass steppe, Chihuahuan desert and Rocky Mountains of the Central United States. Agriculture, Ecosystems and Environment, 24: 307-316.

Walter, D. E. and Proctor, H. C.1999. Mites: Ecology, Evolution and Behaviour. University of New South Wales Press, Sydney, Australia. 